\title{
Simulating the impact of regulation changes on the market for prostitution services
}

Article

Accepted Version

Della Giusta, M. (2010) Simulating the impact of regulation changes on the market for prostitution services. European Journal of Law and Economics, 29 (1). pp. 1-14. ISSN 09291261 doi: https://doi.org/10.1007/s10657-009-9105-y Available at https://centaur.reading.ac.uk/17553/

It is advisable to refer to the publisher's version if you intend to cite from the work. See Guidance on citing.

To link to this article DOI: http://dx.doi.org/10.1007/s10657-009-9105-y

Publisher: Springer

All outputs in CentAUR are protected by Intellectual Property Rights law, including copyright law. Copyright and IPR is retained by the creators or other copyright holders. Terms and conditions for use of this material are defined in the End User Agreement.

$\underline{\text { www.reading.ac.uk/centaur }}$

\section{CentAUR}


Central Archive at the University of Reading

Reading's research outputs online 


\section{Editorial Manager(tm) for European Journal of Law and Economics Manuscript Draft}

Manuscript Number:

Title: Simulating the Impact of Regulation Changes on the Market for Prostitution Services

Article Type: SI (demand supply of prostitution)

Keywords: prostitution, regulation

Corresponding Author: Marina Della Giusta,

Corresponding Author's Institution: University of Reading

First Author: Marina Della Giusta

Order of Authors: Marina Della Giusta; Marina Della Giusta 


\section{Simulating the Impact of Regulation Changes on the Market for Prostitution Services Marina Della Giusta*}

This paper introduces an economic approach to studying prostitution, critically assessing the current limitations of economists' contribution to this important policy debate and illustrating the relative merits of economic modelling for policy design. The first part of the paper reviews the principal contribution to prostitution debates that have informed the formulation of the approach adopted here, and indicates how it differs from other social scientific approaches and from existing work addressing these issues in economics. Central to the approach is the recognition of the role of social stigma in determining the configuration of the exchange of paid sex, and the way in which it is in turn understood and affected by policy (for a discussion of the link between stigma and regulation see Sanders 2007). Drawing on an economic model of the market for prostitution services analysing the interaction between demand and supply for paid sex (Della Giusta, Di Tommaso, and Stroem 2007), the second part describes ways in which different regulatory regimes are chosen by policy makers.

On the part of economists, and also to a large extent feminist economists, there has until recently been a curious reluctance to engage with prostitution as an area of socio-economic life that mobilises large numbers of people and vast amounts of financial

\footnotetext{
${ }^{*}$ I would like to thank Vanessa Munro and collaborators in the Supply/Demand Dynamic in Prostitution seminars for fruitful discussions, as well as the British Academy and the ESRC for funding the organisation of these meetings.
} 
resources internationally. This is all the more surprising since paid sex is, depending on its regulation, either formally or informally part of the entertainment industry, where issues of regulation and labour conditions, particularly given the importance of international migration to the sector, are all well known to economists. The failure to analyse systematically a form of exchange that has many of the features that much recent research in economics claims to want to understand is bewildering, given that the exchange of paid sex appears to incorporate rather obviously issues connected with information and power asymmetries in exchange, ${ }^{1}$ the relationship between formal and informal markets, and the role of regulation in fragmented markets. In addition, the dynamics of international labour mobility, the allocation of resources within the household, women's entrepreneurship, and pathways out of poverty and social exclusion are also implicated. There is an unfortunate parallel between the lack of acknowledgment of prostitution as a form of work in policymaking and in the economic discipline, which by neglecting areas of human economic activity, contributes to their delegitimisation. Given the relevance of the economic profession to policy makers, there is a need for economic research addressing this neglected area of enquiry, learning from the evidence from the sex sector as well as the work carried out in other disciplines.

This paper forms part of a broad economic investigation which was initially inspired by the publication of a contribution by economists to the prostitution literature that appeared to be based on very limited knowledge of the sex industry and on several

\footnotetext{
${ }^{1}$ See the seminal work of Fred Hirsch (1977) and Pagano (1999), widely used among other fields in cooperative and non-cooperative bargaining model of the family.
} 
rather unsatisfactory assumptions (alas, a common feature of our discipline) (see Edlund and Korn 2002). The aim is to contribute an economic understanding of the paid sex exchange that provides opportunities for discussion with other disciplines as well as with policy makers. The discussion begins with an illustration of the main ideas underpinning the economic model contained in Della Giusta et al. (2007), which is then enlarged to illustrate the choice of policy regimes by policy makers.

\section{Economics and Prostitution}

The economic literature has traditionally approached prostitution either showing how it is similar to other markets, or studying it as a form of crime and analysing the costs and benefits of alternative regulatory regimes, generally agreeing that the main motivation behind supply is an economic one (for a review, see Reynolds 1986). More recent theoretical and empirical contributions have focussed on modelling prices and supply characteristics (Cameron et al 1999; Moffatt and Peters 2001; Edlund and Korn 2002; Cameron, 2002), demand determinants (Cameron and Collins 2003), health risk and the effect of condom use on prostitute's earnings (Rao et al 2001; Gertler et al 2003), and, more recently, the evolution of paid sex markets and the ways in which urban spaces favour sexual transactions (Collins 2004). The latter collection is much broader in scope, with paid sex markets being studied as part of the wider sexual market in which people seek partners for reasons that include deficiencies in amount or range of sexual activities in which they participate, or diversification of sexual consumption (Collins 2004, 1634). 
Edlund and Korn (2002) have contentiously modelled prostitution as a highly paid, low skill female occupation alternative to marriage, explaining high wages in terms of a loss of position in the marriage market. ${ }^{2}$ Cameron (2002) provides a more sophisticated explanation for high wages in terms of compensation for social exclusion, risk (assault, disease, arrest, punishment), front loading in wage profile (informal pension scheme or insurance), boredom and physical effort, distaste (potential psychological and physical costs), loss of recreational sex pleasure, anti-social and inconvenient hours, possible excess demand and prices used to screen quality, taboos, and agent fees. Moffatt and Peters (2001) find that prices are affected by duration of the transaction, location, and age of the prostitute, but that other factors affect client satisfaction. Stigma enters these models in the form of a barrier faced by prostitutes when wanting to enter other professions, but it is unrelated to the nature of the transaction between prostitute and client. Cameron and Collins $(2003,274)$ model male clients' decision to enter the market for prostitution services, where he has the choice to derive utility from one relationship partner and/or one paid sex partner. They distinguish between the motivations of men in relationships (variety, specific acts, frequency, outlet for stress) and single men ('relative search costs of finding willing sexual partners, or partners wiling to engage in specific sexual activities in an ad hoc or formal social context, and in a given time period.' An econometric study of the characteristics of male demand for street prostitution services, with the aim of assessing the significance of different types of clients' motivations is contained in Della Giusta et al. (2007b). Garofalo (2002) is so far the only explicitly feminist contribution, and focuses on explaining the different prices paid in the different prostitution sub-markets in terms of the power asymmetries between contractual parties,

\footnotetext{
${ }^{2}$ For a detailed critique see Della Giusta et al (2007)
} 
discussing the role of female prostitution in the construction of male identity. The latter would be at least partly based on asserting control over women through the paid sexual transaction, thereby confirming one's gender identity through the relationship with the opposite one. This links quite well with the evidence from female clients, which exploit various existing 'othering' mechanisms based on class and race, to assert difference and, through the exercise of economic power, control over the male sex workers whose services they buy (see below). Della Giusta et al (2007b) analyse empirically the role of control in demand for sexual services and find that the desire for control is indeed a significant component of demand.

\section{Using an Economic Model of Prostitution to Investigate Policy Alternatives}

The usefulness of economic modelling is that, as long as it is based on valid stylised facts (that is, recurrences encountered in empirical evidence), models can be an extremely useful tool for testing hypotheses, and one whose validity can continuously be checked against empirical evidence. This, of course, is as long as all simplifying assumptions (especially those relating to ceteris paribus, that is the idea that no other factors affecting the model's variables, and not included in the model, will not change simultaneously with the policy parameters of interest) are borne in mind when discussing the policy implications stemming from the model's results. The economic model of prostitution developed in Della Giusta et al (2007) is in the standard rational action tradition (based on the idea that agents make decisions based on the information available to them and having evaluated possible alternatives), but differs in that it contains representative agents 
who are social beings interested, in varying degrees, in the effect of their actions on their reputations, which are socially constructed, both in the sense that they are ascribed rather than intrinsic characteristics, and in the sense that they are affected by what other agents do (so that the relative diffusion of behaviour makes it more acceptable). The economic sociology literature on embeddedness and social capital (Granovetter 1985; Bordieu 1986; Coleman 1988; Putnam 1993; Mansky 2000) points to two distinct ways in which reputations matter to economic agents: first because, as social beings, they derive utility (or satisfaction) from a positive evaluation by others in the social groups they belong to (Casson 1991), and secondly, because they are aware of the costs that social sanctions may impose on their material progress (Akerlof 1980; Arnott and Stiglitz 1991).

Reputation has thus both intrinsic and instrumental value: it is desired per se and can be used to access other earning opportunities. Stigma can thus be understood as a loss of reputation which affects social standing for both clients and sex workers, as well as pay and working conditions in the sex trade and access to services and other jobs for sex workers. The model also incorporates personal differences in concern for reputation depending on agents' personal characteristics and the specific moment at which they exercise choice (so that people are allowed to differ and also to be inconsistent in their choices). This is important in order to describe situations of individuals with high reputation who disregard the effects of their actions, which would be otherwise construed as irrational behaviour. The model considered both the case in which reputational endowments are exogenous (that is not affected by behaviour within the sex industry) and the situation when those endowments are considered endogenous, that is a situation in 
which if a higher quantity of prostitution is sold or bought in the economy the stigma effect decreases. The second key assumption of the model is that the demand for sex and the demand for paid sex are not perfect substitutes to reflect the fact that other motivations, such as desire for control (explored at the empirical level in Della Giusta et al 2007b), underpin demand. Findings from empirical studies of clients suggest that personal characteristics (personal and family background, self-perception, perceptions of women, sexual preferences), economic factors (education, income, work), as well as attitudes towards risk (health hazard and risk of being caught where sex work is illegal), lack of interest in conventional relationships, desire for variety in sexual acts or sexual partners, and viewing sex as a commodity, are all likely to affect demand. For example, Pitts et al (2004) surveyed a sample of 1225 men and women in Australia ${ }^{3}$ and found that $23.4 \%$ had paid for sex at least once. They reported paying for sex to satisfy sexual needs $(43.8 \%)$, because paying for sex is less trouble (36.4\%), and because it is entertaining (35.5\%). Significantly, the researchers found that there were not many significant differences between men who had paid for sex and those who had not, except that the ones who had were on average older, less likely to have university education and to have had a regular partner in the previous year. The motivations of sex workers' clients in the UK (who were all males and appeared to be representatives of all sectors of

\footnotetext{
${ }^{3}$ The sample was taken by distributing a survey to customers of a Sexpo exhibition hold in Melbourne 2001. This is a commercial event hosting a wide range of exhibitors of products associated with sex; of 4.905 respondents, 1225 received a version of the questionnaires with questions on sex workers. Among 1225 respondents, 612 were men and 601 were women.
} 
society) studied in the course of a programme $e^{4}$ on the sex industry presented by Channel 4 appeared to convey the impression that a connection existed between the effort and costs associated with finding a sexual partner who would readily satisfy their sexual preferences, and the straightforward and readily accessible option of sex work. Similar findings are reported by Coy, Horvath and Kelly (2007) on buyers of sex in East London, ${ }^{5}$ as well as by Campbell (1998) and Sanders (2008). This is confirmed by Thorbek and Pattanaik (2002), who draw a sort of "psychological" profile of male sex tourists on the basis of their own descriptions of themselves and accounts of their experiences. This indicates that many of them are finding relationships with others very difficult (either because they do not have the time or the skills required to meet people) and choose sex tourism as an "easier" alternative, which does not imply any responsibility towards the person providing the sexual service. As for the views they held of sex workers, it appears that both sexism and racism mix in determining a very marked distancing, which allow sex tourists to practically ignore and show no interest in the lives and working motivations of the sex workers whose services they buy. Wider phenomena connected to consumerism and globalisation are also clearly related to this industry, which reflects multiple power structures: Marttila (2003) concludes from her study of Finnish clients that: 'the sex business is first and foremost about gendered, economic, social and cultural - global and local - power structures (Marttila 2003, 8). Thus, different intersections of gender, race and class all contribute to the creation of 'othering' mechanisms that serve to both distance the parties to an exchange and justify the

\footnotetext{
${ }^{4}$ Dispatches: Sex on the Street; Channel 4 season Prostitution -The Laws Don't Work, Channel 4, September 2002

${ }^{5} \mathrm{http}: / /$ www.cwasu.org/displayAuthorsPublications.asp?author_key=51
} 
assertion of economic power within it. This phenomenon is obviously not limited to paid sex exchanges, and has been widely documented across a range of personal services (see e.g. Ehrenreich and Hochschild 2003).

As stated in the previous section, gender is also not the only variable at play: women clients are also engaging in sex tourism, as documented both in Thorbek and Pattanaik, and in Sanchez Taylor (2001). The latter, in particular, offers a more in-depth analysis of North American and Northern European women buying sex work services of young men in the Caribbean, in what they themselves describe as 'romance holidays'. Responses to her interviews suggest that, on the one hand, women clients are mostly reluctant to define what they engage in as prostitution, and, on the other, that their ideas about the young men whose service they buy are deeply rooted in racist ideas about black men and black men's sexuality. The theme of inequality appears to be at the core of the relationship: prejudices that allow the stigmatisation of another person as fundamentally “different" and inferior to oneself appear again and again in customers' accounts (BenIsrael et al. 2005; Pitts et al 2004; Kern 2000; Blanchard 1994).

Given these assumptions, the model predicts that client will participate in the 'market' for paid sex if their marginal willingness to pay for exceeds the price of paid sex, plus the marginal costs of a worsened reputation. The higher their reputation capacity (or ability to withstand stigma), the lower is the marginal cost from reputation effects of consuming prostitution, and the more likely it is that prostitution is consumed. Conversely, an individual will start to sell sex if the price of paid sex exceeds its 
opportunity cost, again in terms of reputation and alternative uses of one's time: the higher the price of paid sex, the more likely it is that an individual will supply prostitution; the lower the availability of alternative income, the more likely it is that the individual will take part in the prostitution industry; and the lower the effect of stigma on sex workers, the more likely it is that prostitution will be sold. The equilibrium amount of prostitution sold and bought in the market $\left(\mathrm{S}^{*}\right)$ is a function of the exogenous parameters: reputation capacities of sex workers $\left(R_{p}\right)$ and clients $\left(R_{c}\right)$ and other sources of income for sex workers $\left(\mathrm{H}_{\mathrm{p}}\right)$. The table below describes the changes in both quantity and price $(\mathrm{w})$ of prostitution that result from increases in reputations and alternative earnings.

Table 1. Changes in supply and wages of sex workers resulting from increases in reputation capacities and other earning options

\begin{tabular}{|l|c|c|c|}
\hline Change in & $\mathrm{R}_{\mathrm{c}}$ & $\mathrm{R}_{\mathrm{p}}$ & $\mathrm{H}_{\mathrm{p}}$ \\
\hline $\mathrm{S}^{*}$ & + & + & + \\
\hline $\mathrm{W}$ & + & - & - \\
\hline
\end{tabular}

Column 2 shows that more prostitution is sold at a higher price to clients with a high reputation capacity, that is individuals who are able to cover to a great extent their consumption of prostitution.

Column 3 suggests that if it is difficult to have one's reputation ruined by being found out as a prostitute, then a lot of prostitution will be sold at a low price. This is 
consistent with the evidence of some temporary immigrant prostitutes in Europe who aim to work in prostitution only for a limited amount of time to accumulate savings and then return to their country (see Thorbeke and Pattanaik 2002; Corso and Trifirò 2003).

Column 4 states that the fewer the alternative earning opportunities $\left(\mathrm{H}_{\mathrm{p}}\right.$ high $)$, the more prostitution is sold at a lower price. This is consistent with the evidence from Thailand and other sex tourism destinations where the lack of alternative livelihoods and the power structures within households are important determinants of supply.

In the light of the examples above, policies that were to recognise prostitution as a job and reduce the associated stigma would have the effect of increasing the marginal net gain of supplying prostitution, and increase the marginal willingness to pay for prostitution. This should, in a closed economy, have the effect of increasing the price of prostitution and, given the same availability of alternative earning opportunities (if there are constant intermediation margins), also increase the quantity supplied. However, in an open economy, there always is immigration of illegal workers and out-migration of clients (sex tourism), which would help keeping prices low. Policies that increase the stigma of being clients, conversely, increase the costs associated with being caught for clients. Here, the expectation is that the marginal willingness to pay for prostitution would fall, as would the quantity of prostitution sold and the equilibrium price. However, the evidence from countries that criminalise clients seems to suggest that the response is often a 'going underground' of the sex industry, which increases the risks to which sex 
workers are exposed and does not decrease demand (Sanders 2005), as illustrated by the evidence from community action and displacement of prostitution (Hubbard 1998).

Another strategy followed by intervention programmes has been that of increasing alternative earning opportunities for prostitutes. The effect of these policies will be felt only on that part of prostitution which is supplied for lack of earning alternatives. This implies a fall in part of the supply which will not affect demand and therefore, in an open economy setting, might simply generate displacement of demand, rather than less prostitution being sold at a higher price. Again, this is consistent with the immigration of sex workers operating in the informal sex market which exists in countries that have legalised and have permeable borders (Netherlands).

\section{Thinking About the Effect of Changing Social Norms}

The effect of social norms on people's behaviour has been discussed in economics in the context of studying the ways in which social codes change depending on their degree of acceptance. In particular Akerlof's theory of social custom (Akerlof 1980) incorporates reputation in individual's preferences, and discusses the range of possible market equilibria that exist depending on whether people tend to generally believe or disregard a particular social code within the range of existing ones. This theory was used in our model as a foundation to be able to discuss the ways in which prostitution is stigmatised in different societies. Following the approach of Akerlof, changing social attitudes towards prostitution can be expected to produce different market equilibria in terms of 
the amount of prostitution exchanged, and the price of the service. The reputation function in Akerlof depends on the individual's obedience of the social code and the proportion of the population who believe in that code. Given an increase in demand for sexual services (as documented for example by Day and Ward for the UK), following Akerlof's theory, one would expect that more people would find the exchange of paid sex acceptable, which would appear to be confirmed by data from the UK Survey of Sexual Attitudes. Similarly, Della Giusta et al (2007) investigated the effect of market size on stigmatisation of both customers and sex workers, and suggested different scenarios depending on the degree of independence of mores from behaviour. The rest of this paper is concerned with another aspect of stigmatisation, namely the degree to which policy makers' reputations are affected by the kind of prostitution policy they adopt.

\section{Prostitution Policy}

Introducing policy makers in the simple framework outlined above is no simple matter, as the motivation for regulating this activity is as complex as society's attitude towards it. Furthermore, it has to be borne in mind that most policy regimes have evolved in piecemeal fashion over time, with legislation not explicitly addressing sex work having an important effect. Penal codes reform, public health, social insurance and taxation regimes all play a major part, and more recently concerns over immigration and public order and security are exerting a major influence on policies addressing the sex trade. Defining different 'regimes' should therefore not create the impression that there are coherent alternative models that policy markers choose from. Nonetheless, it seems 
useful to distinguish between the main currently existing models and illustrate how an economic approach to discussing their relative merits would operate. Historically, the prevailing concern informing policies addressing prostitution has been moral and legal sanctioning of those involved in the trade, being directed in different mixtures at sex workers, their clients, or those who organise in a variety of ways the sex trade. The ways in which intermediaries have been addressed by policy is often used as an illustration of the failure to understand the complexity of this activity, with pimps being used as catchall term comprising anyone from people traffickers, to parlour managers and apartment owners, to pushers and sex workers' partners. Policies addressing prostitution directly or indirectly have also been influenced by women's movements and feminist discourses in varying degree, as illustrated by Outshoorn (2004). The welfare of workers in the sex industry has sometimes featured in the discussions, although this has often been accompanied by a rather one-sided understanding of their agency (a point repeatedly discussed in this collection).

In order to describe the main different regimes, Outshoorn's definitions are adopted $(2004,8)$. According to these, abolitionism describes the position whereby prostitution should be banned and third parties, but not prostitutes, criminalised. Prohibitionism indicates instead that all prostitution is declared illegal and parties are held liable to penalties. Finland, for example, moved from being a purely abolitionist regime, with no penalties for prostitutes and sanctions against pimps only to a regime of strong prohibition, which has outlawed prostitutes, clients and pimps (Holli 2004). As is often the case the application of the law differs markedly from the intent of the legislator, 
and the local prostitution ban in Helsinki only resulted in criminalisation of prostitutes rather than clients. Regulation means that the state intervenes in the ways in which the sex industry is run: for example, Australia has seen a trend towards the legalisation of prostitution, with street walking being legal in New South Wales and brothels and escort agencies being legal in a further four territories or states (Sullivan 2004). Most countries fall somewhere between these categories - for example, Austria's approach has been defined as simultaneously regulatory and prohibitive since the legislation on social insurance recognises prostitution as form of work but one which is coercive and immoral (Sauer 2004). Prostitution is permitted in Vienna but not in the provinces, and regulated through registration of prostitutes (although it is estimated that less than $10 \%$ of prostitutes are registered and $85 \%$ are migrant women) and zoning. Meanwhile, brothels are legal, but not bars and private apartments (although prostitution is legal in clients' apartments).

The further category of decriminalisation should also be included in the present discussion, since it has featured quite extensively in discussions in both Canada and the UK, particularly in responses to the consultation launched by the Home Office (Home Office 2004). This approach essentially entails minimal policing and non-intervention. Canada makes it legal to be a prostitute but prohibits all forms of communication for the purposes of prostitution and has dealt with it mostly as a public nuisance (Jeffery 2004). This is in spite of the attempt to decriminalise following the Fraser's committee recommendations in the late 1980 s which went unheeded as the change to a conservative government meant renewed pressure to treat it as a law and order issue. 
Recent reforms in the UK following the consultation by the Home Office (2004 and 2006) entailed a shift from a traditionally abolitionist to an almost prohibitionist regime. There probably are several underlying motives for a move which has discounted expert opinion from a range of scholars, activists and sex workers organisations and pushed towards a stated policy of eliminating sex work by a mixture of exiting and repatriation of immigrant prostitutes, and the adoption of a punitive stance towards clients. Without entering the (de)merits of the actual policy instruments that are being proposed and/or adopted in England and Wales (which are discussed at length by other contributors to this collection), it appears that beneath this change in attitude lies the desire to meet the demands of rather conservative voters (for whom no inconsistency may occur between anti-immigration and anti- kerb crawling views and liberal sex attitudes). This is not surprising, being in line with many of the policies affecting civil liberties currently underway, and not inconsistent with the traditional description of policy makers' behaviour, once their reputation and its effect on re-election chances is considered. Policy makers are usually described in terms of the maximisation of a public welfare function (including costs and benefits to the public from different options) under constraints which describe both the relationships between the variables that are outside the policy makers' control (such as the relationship between inflation and interest rates, or the process of expectations formation) and the incentives of the policy makers (often associated with maintaining power). 
To keep matters simple, let us assume here three different types of costs reflecting the discussion above: policing, administration and public health (indicated by $\mathrm{c}_{\mathrm{p}}, \mathrm{c}_{\mathrm{a}}$ and $\mathrm{c}_{\mathrm{h}}$, respectively). Policing costs include both the cost of monitoring and arresting, as well as the costs from crimes associated with the sex industry. These are assumed to be higher the more punitive the policy regime. Administration costs refer to those from supporting exit strategies in abolitionism (if this is done) and to those from licensing in the case of regulation, and they are assumed here to be the smallest source of costs and smaller than the tax gains from regulation. Public health costs include those associated with sexually transmitted diseases as well as those coming from the other physical and mental damages sustained by sex workers, who feature disproportionately amongst victims of violent crime. Evidence suggests that repressive regimes (prohibition and abolition) increase these costs by pushing prostitution underground and making it difficult for sex workers to protect themselves (see Sanders 2007). Let us also make no assumption regarding the relative magnitudes of policing and health costs ${ }^{6}$.

Let us also assume that policy makers, like clients and sex workers, have reputations (indicated by $\mathrm{R}_{\mathrm{G}}$ ) which reflect their current rating by the general public, and can increase or decrease their rating depending on the policies they adopt, and whether

\footnotetext{
${ }^{6}$ Note that we are not assuming any 'public nuisance' costs here, as the evidence reviewed by the author on regulated streetwalking areas suggests that the perceived sharp trade-off between safe neighbourhoods and streetwalking is largely a result of mis-representation: well managed street walking zones are overwhelmingly located away from residential areas, which tend instead to become used for soliciting in the absence of regulation (and often in association with repressive regimes). For a discussion of displacement see Collins and Judge, in this issue.
} 
these shift opinion in their favour. The point of the electoral cycle of course matters too: the relative importance of reputation will increase the closer to term, since the closer to term it gets, the more the policy maker will be interested in swaying votes it its favour (particularly those from swing voters). Switching between regimes will thus depend on the actual reputation enjoyed by the policy maker and the proximity to elections. If swing voters tend to have views that are fairly conservative, they will be less impressed by liberal policies which may make the sex industry more acceptable and visible (such as regulated brothels), and more in favour of policies that curb it or at least make it less visible. This latter point is rather crucial, since some of the perceived inconsistency of Government policy possibly reflects the attempt to achieve the latter goal, even when the former is stated in principle. It is useful to see, given the assumptions made, what overall incentives the policy maker has to switch away from an existing policy regime. Looking at the separate components of the policy maker's payoff first, and taking prohibition as the basic case, the table below suggests how these may be summarised, given the assumptions outlined above.

\section{Table 2: Changes in policy maker's payoffs when switching from prohibition to different regimes}




\begin{tabular}{|l|l|l|l|l|l|}
\hline Policy regimes & $\begin{array}{l}\text { Reputation } \\
\text { effect }\end{array}$ & $\begin{array}{l}\text { Taxes } \\
\text { on sex } \\
\text { work } \\
\mathrm{T}_{\mathrm{s}}\end{array}$ & $\begin{array}{l}\text { Policing } \\
\text { Costs } \\
\mathrm{c}_{\mathrm{p}}\end{array}$ & $\begin{array}{l}\text { Administration } \\
\text { Costs } \\
\mathrm{c}_{\mathrm{a}}\end{array}$ & $\begin{array}{l}\text { Health } \\
\text { costs } \\
\mathrm{c}_{\mathrm{h}}\end{array}$ \\
\hline $\begin{array}{l}\text { Prohibition } \\
\text { (baseline) }\end{array}$ & None & & None & \\
\hline Abolitionism & $?^{*}$ & 0 & 0 & + & 0 \\
\hline Legalisation & $?^{*}$ & + & - & + & - \\
\hline Decriminalisation & $?^{*}$ & 0 & - & - & - \\
\hline
\end{tabular}

Thus, if all the above assumptions hold, a Government wishing to increase public welfare whilst simultaneously preserving its chances of re-election would move towards less repressive regimes if elections are far away, as these options increase public health and reduce policing costs. However, the same Government will not move away from prohibition if it is close to elections and wishes to maximise its reputation with swing voters. Extending this line of reasoning, a switch from less liberal to more liberal regimes will only occur if the Government is either sure of re-election or far away from it. These results are based on social cost-benefit calculations, but little evidence exists that these are actually performed when deciding between policy options towards this sector, as in other 'morally contentious' policy areas (e.g. drugs).

\section{Conclusions}

The aim of this paper is twofold. On the one hand, it hopes to show how economists can engage in discussions with other disciplines on the complex issues surrounding prostitution. On the other, it seeks to demonstrate how an economic approach can illuminate more clearly some of the outcomes of policy decisions on participants in the 
sex trade, and society more largely, and therefore help policy makers to adopt more systematic approaches based on rigorous evaluation of the costs and benefits associated with different regimes.

At the centre of the approach adopted here is the recognition that stigma plays in prostitution, and the effect it has not just on the reputation of the parties directly involved, but on that of policy makers too. On this basis, a very simple rational action model based on stylised facts from sex trade would suggest liberal policies that maximise public welfare by lifting stigma associated with sector. But, as has been demonstrated, the same rational action model also helps to illustrate why politicians adopt what has often been described as hypocritical behaviour, choosing more repressive regimes which demonstrably worsen the lives of sex workers remaining in the trade, as well as those of society at large.

\section{Appendix}

Formally, if the policy maker maximises the following utility function incorporating both its own reputation and public welfare:

$\operatorname{Max} U\left(R_{G},-C\right)$

where $\mathrm{C}$ is a cost function increasing in all its components $\mathrm{C}\left(\mathrm{c}_{\mathrm{p}}, \mathrm{c}_{\mathrm{a}}, \mathrm{c}_{\mathrm{h}}\right)$ which has an identifiable minimum value, and reputation has a fixed component and a variable component $r_{G}$ reflecting the effect of changing prostitution policy, whose relevance depends on the closeness to election $\operatorname{tr}_{\mathrm{G}}>0$ with $0<\mathrm{t}<1$ where $\mathrm{t}=1$ is election time. 
Thus maximising the policy makers' utility will require simultaneously maximising reputation and minimising costs, that is satisfying the following:

$\operatorname{tr}_{\mathrm{G}}=\mathrm{U}_{\mathrm{c}}{ }^{\prime} \mathrm{C}^{\prime}$

if elections are far, that is $\mathrm{t}=0$, then the policy maker will switch to a regime that minimises costs. Conversely, at election time $\mathrm{t}=1$ and if swing voters are relatively conservative, the policy maker will switch to a regime that increases costs of an amount equal to the reputation increase that the policy maker requires in order to get re-elected.

\section{References}

Akerlof, G. (1980) 'A Theory of Social Custom - of which Unemployment may be One Consequence,' Quarterly Journal of Economics 94:4, 749-775.

Aggleton, P. (ed.) (1998) Men who Sell Sex (London: UCL Press).

Arnott, R. \& Stiglitz J. E. (1991) ,Equilibrium in Insurance Markets with Moral Hazard,' Working Paper No. 3588 (Cambridge, MA: National Bureau of Economic Research).

Bordieu, P. (1986) 'The Forms of Capital,' in Richardson J.G. (ed.), Handbook of Theory and Research for the Sociology of Education (Westport: Greenwood), 241-258.

Bowles, S., Franzini, M. \& Pagano, U. (1999) The Politics and the Economics of Power (London and New York: Routledge). 
Cameron, S. (2002) The Economics of Sin (Cheltenham: Edward Elgar).

Cameron, S. \& Collins A. (2003) 'Estimates of a Model of Male Participation in the Market for Female Heterosexual Prostitution Services,' European Journal of Law and Economics 16:3, 271-288.

Cameron, S., Collins, A.\& Thew, N. (1999) 'Prostitution Services: An Exploratory Empirical Analysis,' Applied Economics 31, 1523-1529.

Campbell, R. (1998) 'Invisible Men: Making Visible Male Clients of Female Prostitutes in Merseyside' in J. E. Elias, V. L. Bullough, V. Elias \& G. Brewer (eds.), Prostitution: On Whores, Hustlers and Johns (Amsherst, NY: Prometheus), 134-154.

Casson, M. (1991) The Economics of Business Culture (Oxford: Clarendon Press).

Chapkis, W. (1997) Live Sex Acts: Women Performing Erotic Labour (New York: Routledge).

Chen, Z. \& Woolley, F. (2001) 'A Cournot-Nash Model of Family Decision Making,' The Economic Journal111, 722-748. 
Coleman, J.S. (1988) 'Social Capital in the Creation of Human Capital', American Journal of Sociology 94, S95-S120.

Collins, A. (ed.) (2004) 'Sex and the City,' Urban Studies 41:9

Corso, C. \& Trifiro, A. (2003) 'E Siamo Partite: Migrazione, tratta e prostituzione straniera in Italia' (Firenze: Giunti).

Della Giusta, M., Di Tommaso, M.L. \& S. Stroem (2007) ‘Sex, Power and Reputation: A Model of the Market for Prostitution Services' Journal of Population Economics, forthcoming (published on line from $6^{\text {th }}$ April 2007, and available at http://www.springerlink.com/content/k2v47x73u2n62604).

Della Giusta, M., Di Tommaso, M.L., Shima, I. \& S. Stroem (2007b) 'What Money Buys: The Demand for Prostitution Services'Applied Economics, forthcoming (published on line from $12^{\text {th }}$ December 2007, and available at http://www.informaworld.com/smpp/content $\sim$ content $=\mathrm{a} 788424853 \sim \mathrm{db}=\mathrm{all} \sim$ order $=$ author

Dobbelsteen, S. \& Kooreman, P. (1997) 'Financial Management, Bargaining and Efficiency within Household: An Empirical Analysis,' De Economist, 145:3, 345-366.

Edlund, L. \& Korn E. (2002) ‘An Economic Theory of Prostitution,' Journal of Political Economy 110: 1, 181-214. 
Ehrenreich, B. \& Russell Hochschild, A. (eds.) (2003) Global Woman: Nannies, Maids, and Sex Workers in the New Economy (New York: Henry Holt and Company).

Garofalo, G. (2002) Towards an Economic Theory of Prostitution (Mimeo: University of Siena).

Gertler, et al. (2003) Risky Business: the Market for Unprotected Prostitution (Mimeo: Cornell University)

Granovetter, M. (1985) 'Economic Action and Social Structure: The Problem of Embeddedness,' American Journal of Sociology 91, 481-510.

Hirsch, F. (1977) Social Limits to Growth (London: Routledge \& Kegan Paul).

Home Office (2004) Paying the Price: A Consultation Paper on Prostitution (London: HMSO).

Home Office (2006) A Coordinated Prostitution Strategy and a Summary of Responses to Paying the Price (London: HMSO).

Hubbard, P. (1998) 'Community Action and the Displacement of Street Prostitution: Evidence from British Cities' Geoforum 29: 3, 269-286. 
Kempadoo, K. \& Doezema, J. (eds.) (1998) Global Sex Workers: Rights, Resistance and Redefinition (London: Routledge).

Kern, R.M. (2000) 'Prostitute Client Profiles: Indicators of Motivations for Prostitution Use,' Archives of Sexual Behaviour 29:2, 165-177.

International Information Centre and Archives for the Women's Movement: www.iiav.nl.

Lim, L. L. (ed.) (1998) The Sex Sector: The Economic and Social Bases of Prostitution in Southeast Asia (Geneva: International Labour Office).

Lundberg, S. \& Pollak, R.A. (1994) 'Non Cooperative Bargaining Models of Marriage,' The American Economic Review 84: 2, 132-137.

Lundberg, S. \& Pollak, R.A. (2003) 'Efficiency in Marriage,' Review of Economics of the Household 1:3, 153-167

Manser, M. \& Brown, M. (1980) 'Marriage and Household Decision Making: a Bargaining Analysis,' International Economic Review 21:1, 31-44.

Mansky, C. (2000) 'Economic Analysis of Social Interactions,' Journal of Economic Perspectives 14, 114-136 
McElroy, M. \& Horney, M.J. (1981) 'Nash-Bargained Household Decisions: Toward a Generalization of the Theory of Demand,' International Economic Review 22:2, 333-349.

McKeganey, N.\& Barnard, M. (1996) Sex work On The Streets: Prostitutes and Their Clients (Buckingham: Open University Press).

Moffatt P.G. \& Peters, S.A. (2001) 'The Pricing of Personal Services,' (Mimeo: Royal Economic Society in Durham, Apr. 2001).

Nussbaum, M. (1999) Sex and Social Justice (New York: Oxford University Press)

O’Connell Davidson, J. (1998) Prostitution Power and Freedom (Cambridge: Polity Press).

O'Kane, M. (2002) 'Prostitution: The Laws Don't Work,' Channel 4 Documentary, UK.

Pateman, C. (1988) The Sexual Contract (Stanford, CA: Stanford University Press).

Rao, V., Gupta, I., Lokshin, M. \& Jana, J. (2001) 'Sex Workers and the Cost of Safe Sex: The compensating Differential for Condom Use in Calcutta' (Mimeo: World Bank).

Reynolds, H. (1986) The Economics of Prostitution (Illinois: CC Thomas). 
Sanders, T. (2008) Paying for Pleasure: Men who Buys Sex (Cullompton: Willan).

Ryley, S. (1936) 'A History of Prostitution form Antiquity to Present' (Delhi: Shubhi Publications), distributed by APH Publishing Corp, 1999. Reprint of the 1936 ed. published by T. W. Laurie, London.

Sanchez Taylor, J. (2001) 'Dollars are a Girl's Best Friend? Female Tourists' Sexual Behaviour in the Caribbean,' Sociology: Identity Politics in the Workplace 35:3, 749-764.

Sanders, T. (2005) Sex Work: A Risky Business (Cullompton: Willan).

Sanders, T. (2007) 'Evidence to Local Government Committee on Prostitution (Public Places) Scotland Bill' from Dr Teela Sanders, University of Leeds http://www.scottish.parliament.uk/business/committees/lg/inquiries/ppp/lg-ppp-

$\underline{\text { Sanders.pdf }}$

Sharpe, K. (1998) Red Light, Blue Light: Prostitutes, Punters and the Police (Aldershot: Ashgate).

Schultz, T.P. (1990) 'Testing the Neoclassical Model of Family Labor Supply and Fertility,' The Journal of Human Resources 25:4, 599-634. 
Thorbek, S. \& Pattanaik, B. (eds.) (2002) Transnational Prostitution: Changing Global Patterns (London: Zed Books).

Tiggey, M., Harocopos, A. Y Hough, M. (2000) 'For Love or Money: Pimps and the Management of Sex Work,' Policing and Reducing Crime Unit (London: Home Office) 